This document was prepared in conjunction with work accomplished under Contract No. DE-AC09-96SR18500 with the U.S. Department of Energy.

This work was prepared under an agreement with and funded by the U.S. Government. Neither the U. S. Government or its employees, nor any of its contractors, subcontractors or their employees, makes any express or implied: 1 . warranty or assumes any legal liability for the accuracy, completeness, or for the use or results of such use of any information, product, or process disclosed; or 2 . representation that such use or results of such use would not infringe privately owned rights; or 3 . endorsement or recommendation of any specifically identified commercial product, process, or service. Any views and opinions of authors expressed in this work do not necessarily state or reflect those of the United States Government, or its contractors, or subcontractors. 


\section{TENSILE TESTING OF CARBON STEEL IN HIGH PRESSURE HYDROGEN}

\author{
Andrew Duncan \\ Savannah River National Laboratory \\ Aiken, South Carolina, 29808
}

\author{
Poh-Sang Lam \\ Savannah River National Laboratory \\ Aiken, South Carolina, 29808
}

\author{
Thad Adams \\ Savannah River National Laboratory \\ Aiken, South Carolina, 29808
}

\begin{abstract}
An infrastructure of new and existing pipelines and systems will be required to carry and to deliver hydrogen as an alternative energy source under the hydrogen economy. Carbon and low alloy steels of moderate strength are currently used in hydrogen delivery systems as well as in the existing natural gas systems. It is critical to understand the material response of these standard pipeline materials when they are subjected to pressurized hydrogen environments. The methods and results from a testing program to quantify hydrogen effects on mechanical properties of carbon steel pipeline and pipeline weld materials are provided. Tensile properties of one type of steel (A106 Grade B) in base metal, welded and heat affected zone conditions were tested at room temperature in air and high pressure (10.34 MPa or 1500 psig) hydrogen. A general reduction in the materials ability to plastically deform was noted in this material when specimens were tested in hydrogen. Furthermore, the primary mode of fracture was changed from ductile rupture in air to cleavage with secondary tearing in hydrogen. The mechanical test results will be applied in future analyses to evaluate service life of the pipelines. The results are also envisioned to be part of the bases for construction codes and structural integrity demonstrations for hydrogen service pipeline and vessels.
\end{abstract}

\section{INTRODUCTION}

The effect of gaseous hydrogen on materials is not a new phenomenon. Science and industry have noted a propensity for reduced ductility and resistance to fracture in ferritic steels as a result of exposure to hydrogen environments ${ }^{1}$. This reduction is most prevalent at ambient or just below ambient temperatures and is also enhanced at slow strain rates ${ }^{2}$. The tensile properties found in the literature typically include one or more of the following: yield stress, ultimate tensile strength, elongation, and reduction of area $^{3}$. They were reported mainly to demonstrate the hydrogen effects at various levels of pressure or concentration. The data may be useful for codified analyses which require strength information of the steels. However, for a realistic structural analysis or fracture performance analysis with the finite element method, in general, a full stress-strain curve beyond linear elasticity (up to failure) would be required. Furthermore, a mechanical properties database should be developed for each material selected for this type of application, in order to provide a consensus of properties for design of hydrogen systems. This requires the use of a statistically valid number of specimens for each testing condition.

Much of the experimental in this area has yielded data which is more applicable to academic study of the subject. A report on the hydrogen embrittlement effects on various structural alloys including (but not limited to) carbon steels can be found in the literature, which is a summary of a research project sponsored by National Aeronautics and Space Administration (NASA) prior to $1973^{4}$. In the experimental programs for the tensile properties, the researchers used unnotched and notched specimens. The notched specimens provided stress concentration in the gage section so the hydrogen concentration is enhanced locally resulting in a more pronounced effect. This technique is a good screening criterion for determining hydrogen effects on specific metals and alloys. However, the test data generated this type of specimen may be 
inadequate for stress analysis in structural integrity-related issues $^{3}$. In addition, the data did not address the specific steels of interest for piping systems or the effect of hydrogen on welded regions and heat affected zones (HAZ's).

The tensile and fatigue properties have been obtained in 1000 psig (6.9 MPa) hydrogen environment for some API pipeline materials ${ }^{5}$ (X42 and X70) and low carbon steels (A516 and A106B) and were reported by Cialone and Holbrook ${ }^{6}$, as well as other studies ${ }^{7,8}$. The tensile results from these reports are consolidated in Table I. The yield stress and UTS do not reveal any consistent trends when comparing the specimens tested in air with those tested in hydrogen. In most cases, a slight reduction in elongation was noted when the steel specimens were tested in $6.9 \mathrm{MPa}$ hydrogen. However, in every case the reduction of area (RA) measured showed a slight decline in hydrogen.

Table I: Tensile properties for X42, X70, A516, and A106B in air and in 6.9 MPa (1000 psi) hydrogen gas (shaded) $)^{6-8}$.

\begin{tabular}{|l|l|c|c|c|c|}
\hline Steel & Environ. & $\begin{array}{c}0.2 \% \\
\text { Yield } \\
\mathrm{MPa}\end{array}$ & $\begin{array}{c}\text { UTS } \\
\text { MPa }\end{array}$ & $\begin{array}{c}\text { Elong } \\
\%\end{array}$ & $\begin{array}{c}\text { Reduction } \\
\text { of Area } \\
\%\end{array}$ \\
\hline $\begin{array}{l}\text { X42 } \\
\text { Long. }\end{array}$ & Air & 366 & 511 & 21 & 56 \\
\cline { 2 - 6 } & $6.9 \mathrm{MPa} \mathrm{H}_{2}$ & 331 & 483 & 20 & 44 \\
\hline $\begin{array}{l}\text { X42 } \\
\text { Trans. }\end{array}$ & Air & 311 & 490 & 21 & 52 \\
\cline { 2 - 6 } & $6.9 \mathrm{MPa} \mathrm{H}_{2}$ & 338 & 476 & 19 & 41 \\
\hline $\begin{array}{l}\text { X70 } \\
\text { Long. }\end{array}$ & Air & 584 & 669 & 20 & 57 \\
\cline { 2 - 6 } & $6.9 \mathrm{MPa} \mathrm{H}_{2}$ & 548 & 659 & 20 & 47 \\
\hline $\begin{array}{l}\text { X70 } \\
\text { Trans. }\end{array}$ & Air & 613 & 702 & 19 & 53 \\
\cline { 2 - 6 } & $6.9 \mathrm{MPa} \mathrm{H}_{2}$ & 593 & 686 & 15 & 38 \\
\hline $\begin{array}{l}\text { A516 } \\
8\end{array}$ & Air & 372 & 538 & 17 & 70 \\
\cline { 2 - 6 } & $6.9 \mathrm{MPa} \mathrm{H}_{2}$ & 365 & 552 & 20 & 43 \\
\hline $\begin{array}{l}\text { A106 } \\
\text { B }\end{array}$ & Air & 462 & 558 & 14 & 58 \\
\cline { 2 - 6 } & $6.9 \mathrm{MPa} \mathrm{H}_{2}$ & 503 & 579 & 11 & 50 \\
\hline
\end{tabular}

AElongation \% was reported for a 1" $(25.4 \mathrm{~mm})$ gage length

The present work summarizes continued study in this area in order to collect a data set large enough to determine the effect of hydrogen on properties in a method that is statistically valid and quantitative. Furthermore, this database will provide not only properties but the entire the entire stress-strain curve for a material. Hence, the need for continued testing of this class of steels in hydrogen environments is still present. This has prompted a renewed interest in testing these materials in hydrogen environments. Tensile testing of carbon steel in hydrogen atmospheres (up to $10.3 \mathrm{MPa}$ or $1500 \mathrm{psi}$ ) was planned to develop a data set for transmission pipelines. Of alloys initially considered, ASTM A106 grade B was chosen because of its wide utilization in the pipeline industry. The compositional requirements for this steel are listed in Table II. The pipe section was chosen because the available wall thickness left ample material for the machining of specimens and could be sectioned with the entire gage section intersecting the base metal, weld metal or HAZ. This paper documents the results from the tensile tests of specimens machined from this welded pipe section.

Table II: Alloy Composition and Tensile Properties for A 106 Grade B Pipe Material ${ }^{9}$

\begin{tabular}{|c|c|}
\hline \multicolumn{2}{|c|}{ A 106 Grade B } \\
\hline Element/Property & Composition, \% \\
\hline Carbon, $\max ^{\mathrm{A}}$ & 0.3 \\
\hline Manganese & $0.29-1.06$ \\
\hline Phosphorus, max & 0.035 \\
\hline Sulfur, max & 0.035 \\
\hline Silicon, min & 0.10 \\
\hline Chrome, $\max ^{\mathrm{B}}$ & 0.40 \\
\hline Copper, $\max ^{\mathrm{B}}$ & 0.40 \\
\hline $\begin{array}{l}\text { Molybdenum, } \\
\text { max }^{B}\end{array}$ & 0.15 \\
\hline Nickel, $\max ^{\mathrm{B}}$ & 0.40 \\
\hline Vanadium, $\max ^{\mathrm{B}}$ & 0.08 \\
\hline $\begin{array}{l}0.2 \% \text { Yield Stress } \\
(\mathrm{MPa})\end{array}$ & 240 \\
\hline $\begin{array}{l}\text { Ultimate Tensile } \\
\text { Stress }(\mathrm{MPa})\end{array}$ & 400 \\
\hline $\begin{array}{l}\text { Elongation (\%) for } \\
50 \mathrm{~mm} \text { gage length }\end{array}$ & 30 (16.5 trans.) \\
\hline $\begin{array}{l}\text { Reduction in Area } \\
(\%)\end{array}$ & $\mathrm{N} / \mathrm{A}$ \\
\hline
\end{tabular}

${ }^{A}$ For each reduction of $0.01 \%$ below the specified carbon maximum, an increase of $0.06 \%$ manganese above the specified maximum will be permitted up to a maximum of $1.35 \%$.

${ }^{\mathrm{B}}$ These five elements combined shall not exceed $1 \%$.

\section{EXPERIMENTAL}

A section of 4 inch pipe (4.5 inches OD X 0.674 inches wall thickness) was circumferentially welded using welding procedure specification WPS-P1-TA ${ }^{\dagger 10}$. The multipass SMAW weld was performed with certification and without any post weld heat treatment (PWHT). In this specification, no PWHT is required unless lines are intended for caustic service or wall thickness is $>19 \mathrm{~mm}$ (i.e., 0.75 inches). The root pass of the weld was performed by gas tungsten arc welding

$\dagger$ This site specific procedure specification was qualified to the ASME Boiler and Pressure Vessel Code, Section IX, "Welding and Brazing Qualifications" 
(GTAW) with filler rod ER70S-2 filler rod, while each remaining pass used shielded metal arc welding (SMAW) with E7018 filler rod. Figure 1 shows a picture of the pipe section after welding.

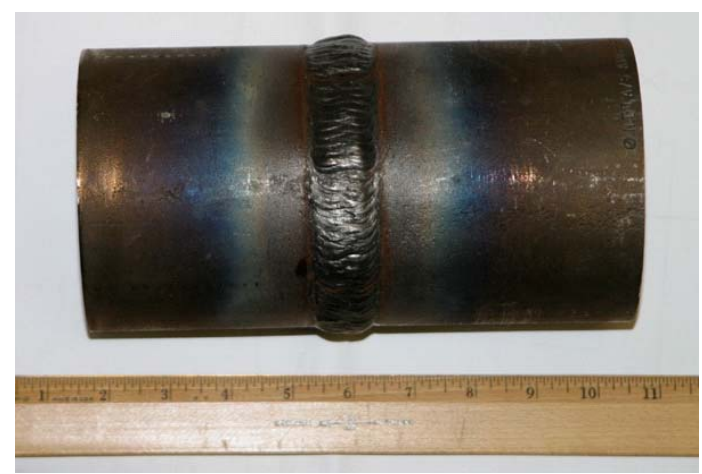

Figure 1: Photograph of Alloy A 106 Grade B Pipe Section after Welding

After the weld procedure was complete the pipe was sectioned using electro-discharge milling (EDM) and tensile specimens were machined in the L-C orientation (see Figure 2). Specimens were machined in a "dog bone" configuration from the pipe section with the gage section intersecting the base metal, weld metal or HAZ regions of the pipe (see Figure 3). The initial tests were performed at ambient temperatures and atmospheric conditions. Additional samples were tested in 10.3 MPa (1500 psig) research grade hydrogen gas ( $99.999 \%$ pure).

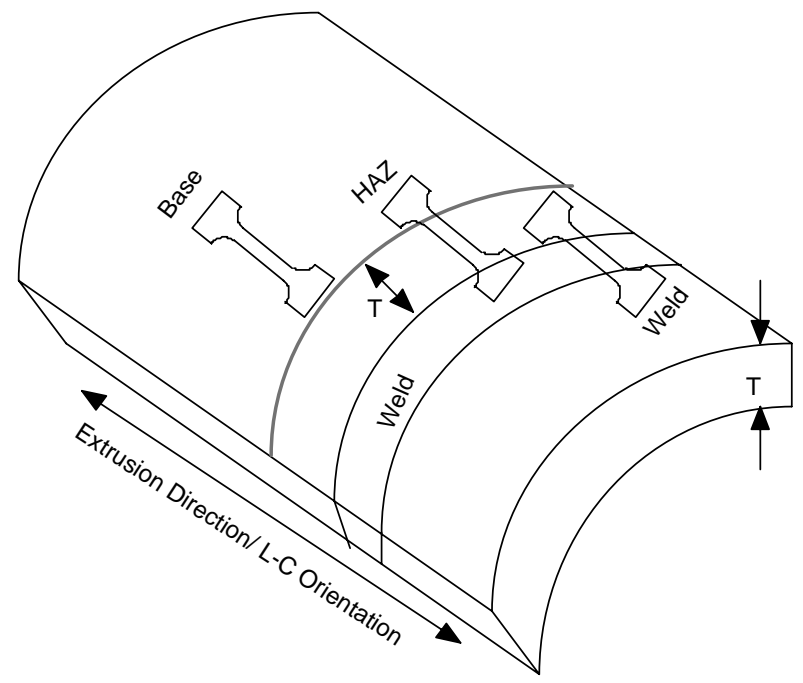

Figure 2: Schematic of Pipe Section illustrating the Orientation of Tensile Specimens

The specimens were tested at room temperature (i.e. $64-78^{\circ} \mathrm{F}$ ) on a screw driven MTS Sintech Renew ${ }^{\mathrm{TM}} 1125$ load frame with a $455 \mathrm{~kg}$ load cell at a strain rate of $1 \times 10^{-4} / \mathrm{sec}$. The load frame is located inside a hydrogen environmental test facility at SRNL which utilizes engineering controls to ensure flammable gas concentrations in the facility are maintained below the lower flammability limit and engineered barriers to protect personnel. The data was collected using MTS Testworks ${ }^{\mathrm{TM}} \mathrm{v} 3.1$ data acquisition software.

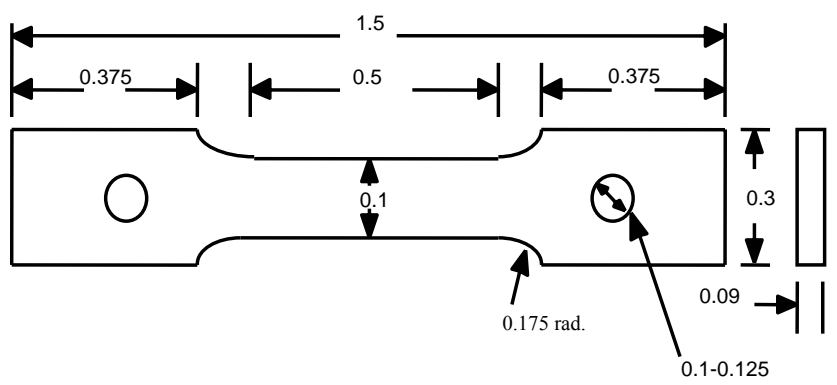

All dimensions in inches

Figure 3: Schematic and Dimensions of Dog bone Tensile Specimen

The specimens that were tested in hydrogen were loaded into a high-pressure vessel manufactured by Autoclave Engineering ${ }^{\mathrm{TM}}$ that is equipped with a translational feedthrough. The chamber was constrained in the load frame (to prevent premature loading of the specimen), purged with inert gas several times and pressurized to $10.3 \mathrm{MPa}$. The soak time in hydrogen gas, at pressure, was 30 minutes and was estimated based on the diffusion coefficient for hydrogen in iron $^{\$ 11}$. The pressure was controlled remotely using an independent control system utilizing LabView ${ }^{\mathrm{TM}}$ v5.0 software. A picture of the test set up is shown in Figure 4. In the present study, 6 test conditions (base metal, weld or HAZ in air or $\mathrm{H}_{2}$ ) with 6 specimens per test condition were performed. A total of 36 specimens were tested (18 in air and 18 in hydrogen). On occasion, difficulties with the data acquisition system or test equipment required an additional specimen be tested.

The tests were performed to failure and the specimens were examined after the test to measure reduction in area, to verify plastic strain to failure and to characterize the fracture surface. Optical microscopy and scanning electron microscopy were utilized to accomplish this analysis. The raw data of load and crosshead deflection were analyzed using a technique to compensate for machine compliance and slippage in the grip section. The procedure for this correction is described in a study by Lam et al. ${ }^{12}$. Engineering stress and strain were calculated and $0.2 \%$ Yield stress, ultimate tensile strength and ductility at failure were determined from the stress strain curves.

Soak time is determined using the equation: $\mathrm{x} \approx \sqrt{\mathrm{D} t}$, where $\mathrm{x}$ is distance into sample ( $1 / 2$ sample thickness), $\mathrm{D}$ is the diffusion coefficient for hydrogen in bcc iron at room temperature $\left(\mathrm{D} \approx 9.2 \times 10^{-5} \mathrm{~cm}^{2} / \mathrm{s}\right)$ and $\mathrm{t}$ is the time at pressure. To ensure adequate time, a soak time was selected that is roughly 10 times the required time at pressure. 


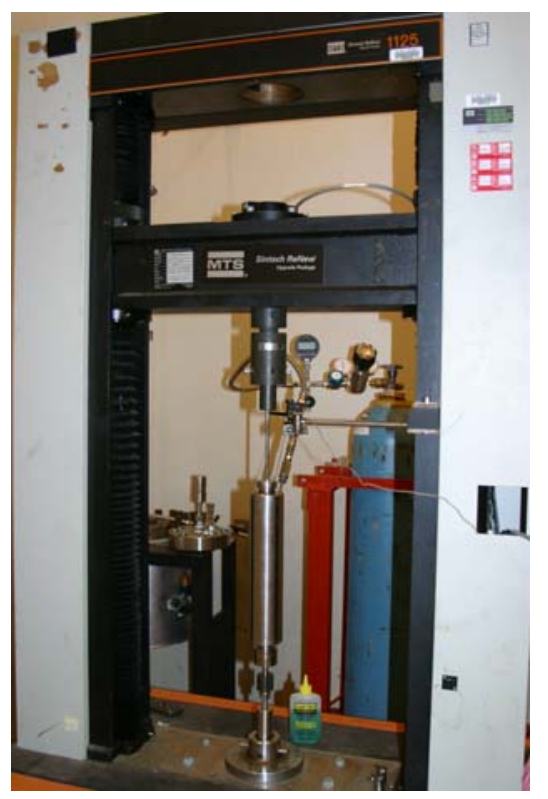

Figure 4: Hydrogen Test Load Frame Set Up and Configuration

\section{RESULTS AND DISCUSSION}

The changes resulting from exposure of carbon steels to hydrogen environments is well known ${ }^{1,3}$. The deformation capacity (ductility), fracture mechanics properties including fracture toughness and fatigue crack propagation characteristics are deteriorated as the hydrogen pressure increases. The behavior of the "deformation capacity" is illustrated when the fracture surfaces of tensile specimens are examined for specimens tested in air versus hydrogen. For example, Figure 5 ( $a$ and $b$ ) shows the fracture surfaces for the HAZ tensile specimens tested in air and $10.3 \mathrm{MPa}$ hydrogen at low magnification.

Figure 6 (a and $b$ ) shows the fracture surfaces for the same HAZ tensile specimens at higher magnification. From these figures, the effects of hydrogen on the deformation capacity can be readily observed. Specifically, the overall "reduction in area" in the necked region is significantly greater in the specimen tested in air (see Figure 5). The morphology of the fracture surface is also changed; Figure 6 shows a reduction in ductile rupture (i.e., void growth and coalescence ${ }^{13}$ ) in the specimen tested in hydrogen. This behavior is consistent with what has been observed in studies, previously ${ }^{7,14}$.

The engineering stress vs. engineering strain curves are presented in Figures 7-9 for typical specimens at each condition. The average mechanical property data for the test matrix is presented in Table III. In comparison to the previous studies $^{6,7}$ (see Table I), the yield and UTS is significantly lower and the elongation higher. However, these properties are well within the allowance in the specification (see Table II).

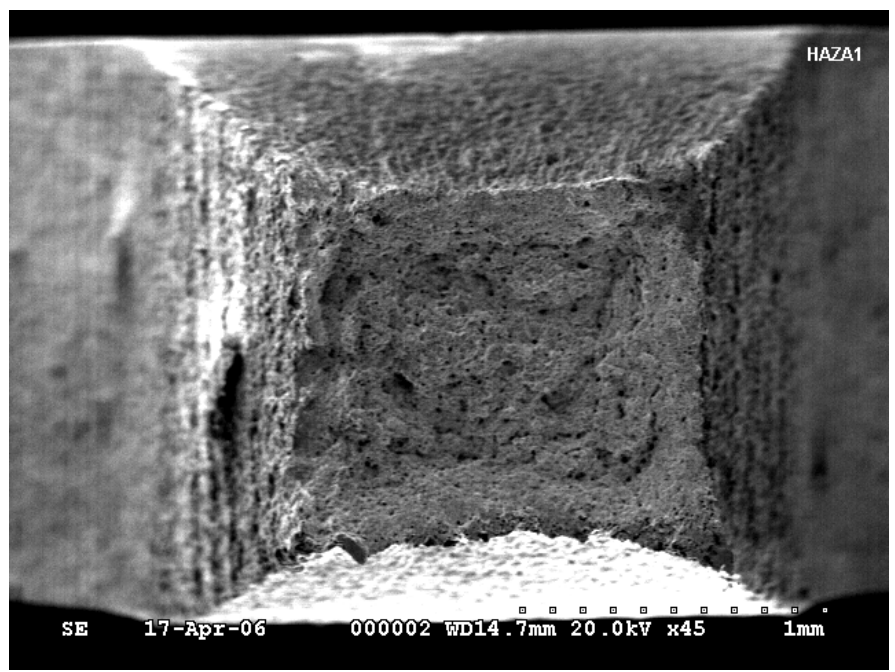

(a)

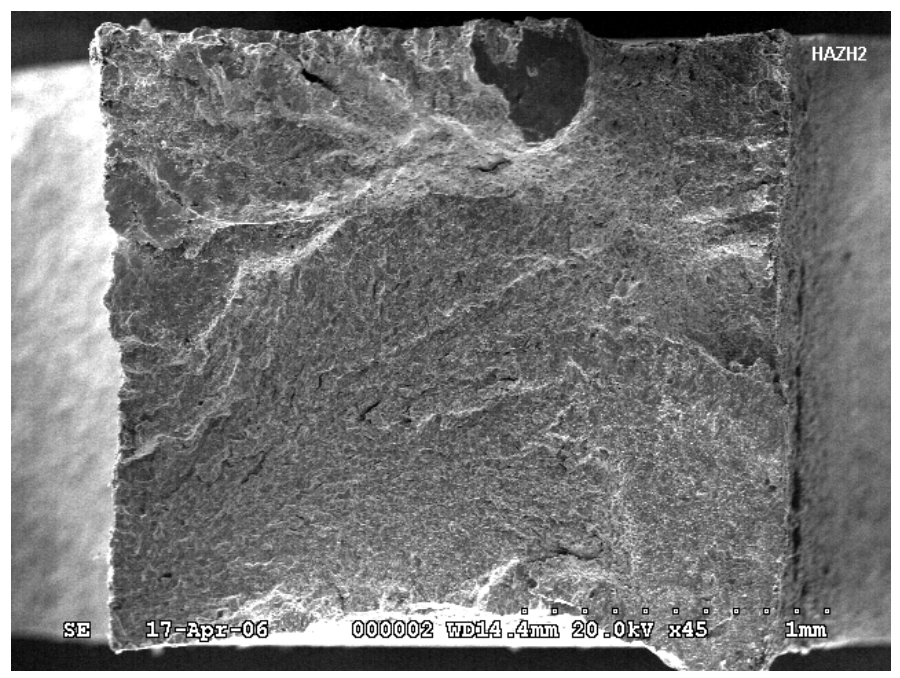

(b)

Figure 5: Low Magnification Scanning Electron Micrographs of the Fracture Surface from HAZ Specimens Tested in Air (a) and 1500 psig Hydrogen (b)

From the presentation of the data, it can be observed that no significant changes occur in yield stress or ultimate tensile stress. However, a reduction in the elongation to failure is observed. Reduction of area (RA) is a property that must be measured after the test and may be more sensitive to small differences in the deformation behavior of the material. An indication of the effect of hydrogen on this property can be seen in Table IV. Figure 5 also illustrates the significant difference indicated in Table IV for HAZ samples. This effect is also evident in the RA measurements of base metal and weld metal samples (see Table IV). The change in RA noted in Table IV is more pronounced than the values observed by the previous studies ${ }^{7,8}$ but still exhibits the same trend. The typical stress vs. strain curves in Figures 7-9, for each type of specimen may help explain the underlying cause of this 
behavior. Specifically, the samples tested in hydrogen, appear to experience a more drastic drop off in stress once the UTS is reached than those samples tested in air. Surface cracks were observed in the gage section of these specimens near the fracture surface. The presence of these surface cracks were also noted by Jewett et al. ${ }^{4}$ in several alloys and were described to be deeper for severely embrittled alloys. The result of their presence, is the specimen has less of an opportunity for the formation of necking and larger final fracture area. This behavior would indicate that fracture toughness and crack propagation of the steels will be affected at these pressures of hydrogen. These tests are currently in progress and will be reported in a subsequent paper.

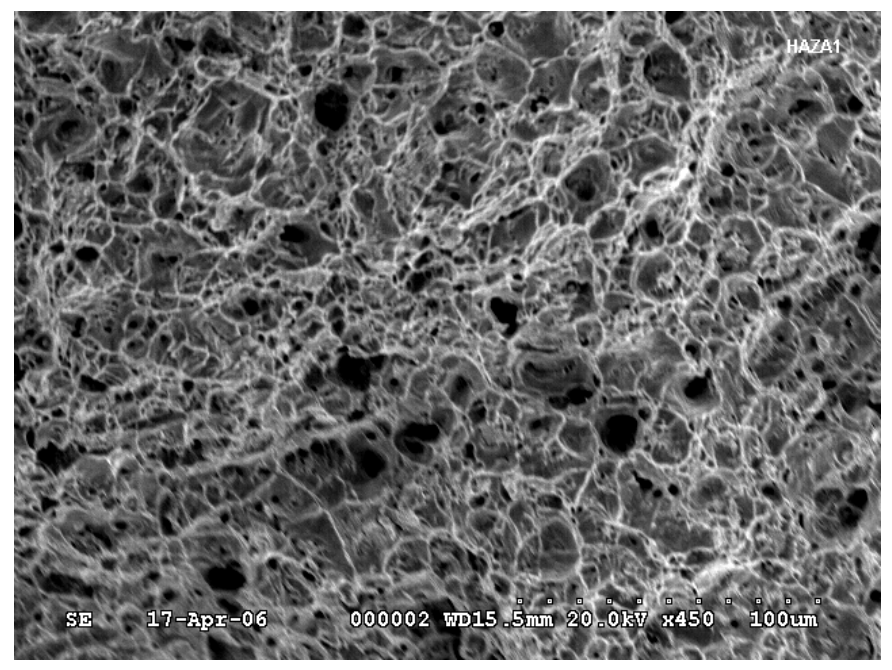

(a)

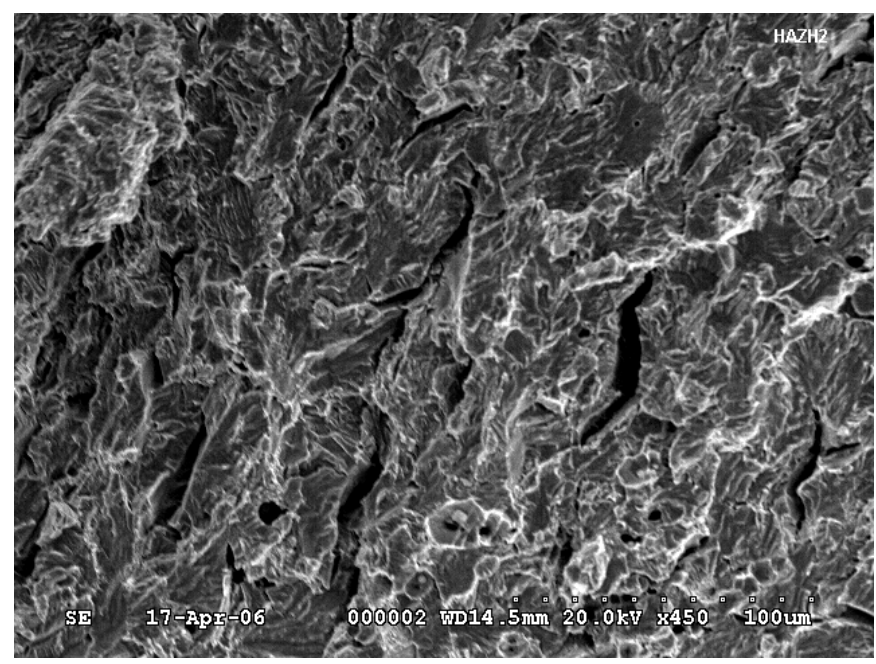

(b)

Figure 6: Higher Magnification Scanning Electron Micrographs of the Fracture Surface from HAZ Specimens Tested in Air (a) and 1500 psig Hydrogen (b)

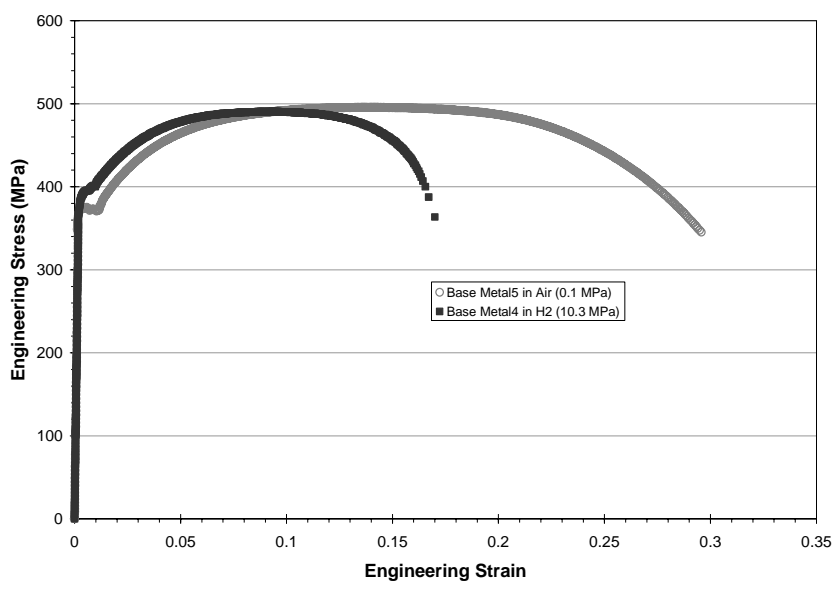

Figure 7: Engineering Stress vs. Strain for Base Metal in Air and Hydrogen

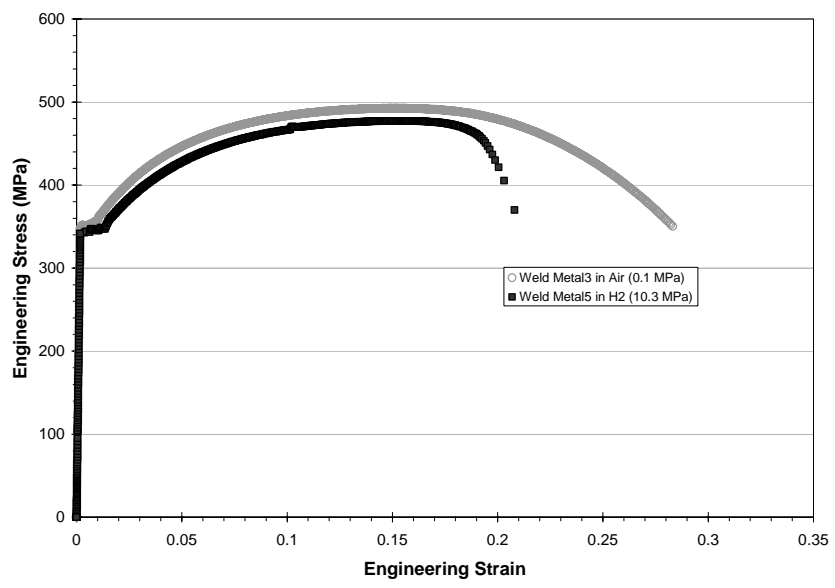

Figure 8: Engineering Stress vs. Strain for Weld Metal in Air and Hydrogen

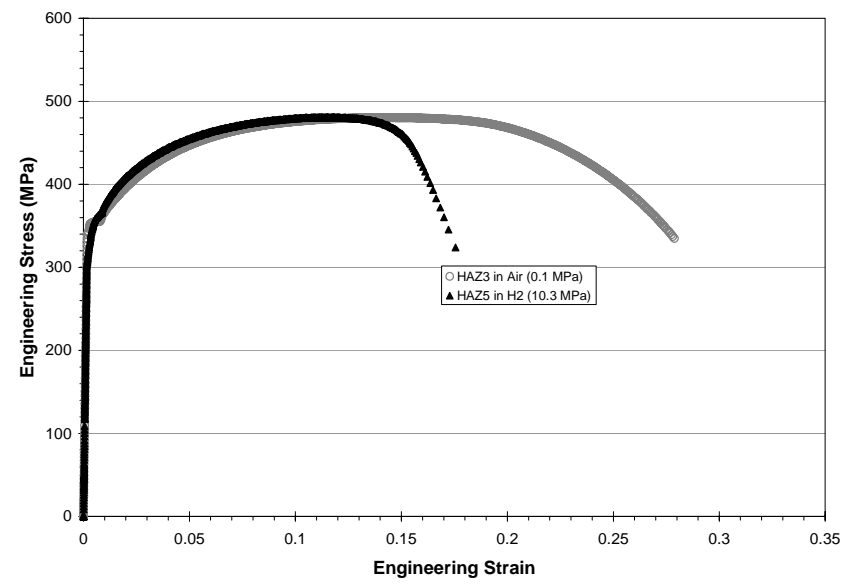

Figure 9: Engineering Stress vs. Strain for HAZ Metal in Air and Hydrogen 
Table III: Average Tensile Property Results with standard deviation $(\chi \pm s)$.in Air and Hydrogen (shaded).

\begin{tabular}{|c|c|c|c|c|c|c|c|}
\hline & \multicolumn{6}{|c|}{ Average Properties } \\
\hline & & $\begin{array}{l}0.2 \% \\
\text { Yield } \\
\text { (MPa) }\end{array}$ & Dev. & $\begin{array}{c}\text { UTS } \\
\text { (MPa) }\end{array}$ & Dev. & $\begin{array}{l}\text { Elong. } \\
\text { at } \\
\text { failure }\end{array}$ & Dev. \\
\hline \multirow{2}{*}{ ڤ్ } & Air & 355.3 & 15.8 & 484.6 & 8.6 & 0.29 & 0.04 \\
\hline & $\mathrm{H}_{2}$ & 357.1 & 32.9 & 486.4 & 17.8 & 0.19 & 0.04 \\
\hline \multirow{2}{*}{ 힐 } & Air & 343.0 & 20.0 & 490.4 & 9.0 & 0.28 & 0.01 \\
\hline & $\mathrm{H}_{2}$ & 350.0 & 16.1 & 480.9 & 12.0 & 0.21 & 0.02 \\
\hline \multirow{2}{*}{$\frac{N}{X}$} & Air & 349.3 & 20.8 & 482.3 & 7.6 & 0.27 & 0.04 \\
\hline & $\mathrm{H}_{2}$ & 338.2 & 18.5 & 475.5 & 9.6 & 0.19 & 0.04 \\
\hline
\end{tabular}

Table IV: Reduction of Area for Samples in Air and Hydrogen (shaded) with standard deviation $(\chi \pm s)$

\begin{tabular}{|c|c|c|c|}
\hline & Environment & $\begin{array}{c}\text { Average Pr } \\
\text { Reduction of } \\
\text { Area (\%) }\end{array}$ & $\begin{array}{l}\text { rty } \\
\text { Dev. }\end{array}$ \\
\hline \multirow{2}{*}{$\begin{array}{l}\ddot{\Delta} \\
\ddot{\oplus}\end{array}$} & Air & 68.6 & 1.5 \\
\hline & $\mathbf{H}_{2}$ & 30.8 & 5.0 \\
\hline \multirow{2}{*}{$\frac{\pi}{0}$} & Air & 74.9 & 2.2 \\
\hline & $\mathbf{H}_{2}$ & 30.5 & 6.4 \\
\hline \multirow{2}{*}{ 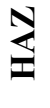 } & Air & 71.0 & 1.7 \\
\hline & $\mathrm{H}_{2}$ & 30.4 & 6.8 \\
\hline
\end{tabular}

\section{SUMMARY AND PATH FORWARD}

This study reports the results from the tensile testing of A106 grade B carbon steel base metal, weld fusion metal and HAZ's. The program was conducted in support of an evaluation of the use of new and existing pipelines and systems to carry and to deliver hydrogen as an alternative energy source under the hydrogen economy. The grade of carbon steel was selected because of its common application in pipelines. The results of a matrix of tensile tests performed at room temperature in air and in high pressure hydrogen were reported.

A general reduction of the ductility or deformation capacity was noted in this material. The elongation to failure and reduction in area were reduced when specimens were tested in 10.3 MPa hydrogen. Furthermore, the primary mode of fracture changed from ductile rupture to more of a quasicleavage.
Tests to quantify the fracture behavior in terms of J-R curves for these materials at air and hydrogen pressure conditions are ongoing.

\section{ACKNOWLEDGMENTS}

This work was supported by Concurrent Technologies Corporation (CTC) and the Department of Energy office of Energy Efficiency and Renewable Energy (DOE-EERE). The support and guidance of Robert Dax, Linda Eslin, Dave Moyer and Kevin Klug from CTC is most appreciated. The technical input of Glenn Chapman, Mike Morgan, George Rawls, David Maxwell and Joel Jones from SRNL is also gratefully acknowledged.

\section{REFERENCES}

${ }^{1}$ M. R. Louthan Jr., "Effects of Hydrogen on the Mechanical Properties of Low Carbon and Austenitic Steels," Hydrogen in Metals, Vol. 2, pp. 53-75, Eds. I. M. Bernstein and A. W. Thompson, American Society for Metals, Metals Park, $\mathrm{OH}$ (1974)

2 G. E. Dieter, Mechanical Metallurgy, $3^{\text {rd }}$ edition, p490, McGraw-Hill, New York, NY (1986).

3 P. S. Lam, "Gaseous Hydrogen Effects on the Mechanical Properties of Carbon and Low Alloy Steels (U), Technical Report \# WSRC-TR-2006-00119 Rev 1, March (2206).

4 Jewett, R. P., Walter, R. J., Chandler, W. T., and Frohmberg, R. P., 1973, Hydrogen Environment Embrittlement of Metals, prepared by Rocketdyne, Division of North American Rockwell, Canoga Park, CA. for National Aeronautics and Space Administration, Washington, DC, NASA Contractor Report NASA CR-2163.

5 Specification for Line Pipe, API Specification 5L, 43rd Edition, March 2004, American Petroleum Institute, Washington, DC.

${ }^{6}$ Cialone, H. J. and Holbrook, J. H., 1988, "Sensitivity of Steels to Degradation in Gaseous Hydrogen," Hydrogen Embrittlement: Prevention and Control, ASTM STP 962, ed. L. Raymond, American Society for Testing and Materials, Philadelphia, pp. 134-152.

${ }^{7}$ Holbrook, J. H., Cialone, H. J., Mayfield, M. E., and Scott, P. M., 1982, The Effect of Hydrogen on Low-Cycle-Fatigue and Subcritical Crack Growth in Pipeline Steels, Battelle Columbus Laboratories, Columbus, Ohio, available through U. S. Department of Commerce, National Technical Information Service, DE85006685.

${ }^{8}$ W. R. Hoover, S. L. Robinson, R. E. Stoltz and J. R. Spingarn, "Hydrogen Compatibility of Structural Materials for Energy Storage and Transmission. Final Report" Report \# SAND-81-8006, Sandia National Labs., Livermore, CA May (1981).

9 ASTM Designation \#A106-06, Standard Specification for Seamless Carbon Steel Pipe for High-Temperature Service, 
American Society for Testing Materials, West Conshohoken, PA (2006)

${ }^{10}$ WPS \# P1-TA, Rev. 2 SRS Welding Procedure Specification for Welding Carbon Steel Using the GTAW and SMAW Processes, SRS, Aiken, SC, 9/26/03.

${ }^{11}$ N.R. Quick, H.H. Johnson, "Hydrogen and Deuterium in Iron, 49-506 C.", Acta Met Vol. 26 pp 903-907 (1978).

${ }^{12}$ Lam, P.S., Morgan M. J., Imrich K. J. and Chapman, G. K., "Predicting Tritium and Decay Helium Effects on Burst Properties of Pressure Vessels," Proceedings of PVP2006ICPVT-11: 2006 ASME Pressure Vessels and Piping Conference July 23-27, 2006, Vancouver, BC, Canada

13 R. W. K. Honeycombe, Steels: Microstructure and Properties, pp 196-201, American Society for Metals, Metals Park, OH 44073 (1982).

${ }^{14}$ S. L. Robinson and R. E. Stolz, "Toughness Losses and Fracture Behavior of Low Strength Carbon Manganese Steels in Hydrogen," Hydrogen Effects in Metals, pp. 987995, Eds. I. M. Bernstein and A. W. Thompson, The Metallurgical Society, Warrendale, PA 15086 (1981). 